\title{
Studi Kekeringan Meteorologi dengan Menggunakan Metode Standardized Precipitation Index (SPI) dan China Z Index (CZI) di DAS Lekso Kabupaten Blitar
}

\author{
Firda Novita $^{1 *}$, Donny Harisuseno ${ }^{1}$, Ery Suhartanto ${ }^{1}$ \\ ${ }^{1}$ Jurusan Teknik Pengairan, Fakultas Teknik, Universitas Brawijaya, \\ Jalan MT. Haryono No. 167, Malang, 65145, INDONESIA \\ *Korespondensi Email: firdanovita1@gmail.com
}

\begin{abstract}
Blitar Regency is one of the areas that prone to drought, one of them is DAS Lekso. The lack of rainfall causes the drought that occurs in Blitar Regency. Therefore, initial efforts are needed to mitigate meteorological drought by monitoring and analyzing the drought characteristic in the study area. The drought analysis was conducted using Standardized Precipitation Index (SPI) method and China Z Index (CZI) method where the drought resulted from each method was compared with the data of Southern Oscillation Index (SOI). Further, a map of drought distribution was developed using Geographic Information System (GIS) with Kriging interpolation. The result of the comparison analysis on monthly basis showed the percentage $57.45 \%$ and $42.55 \%$ for SPI and CZI method respectively while $63 \%$ and $60 \%$ on the annual basis. The results of the correlation analysis between drought index and rainfall data demonstrated that the CZI method showed a better correlation that the SPI method. Therefore, the CZI method was recommended as a suitable tool to estimate drought-affected villages using kriging interpolation in study area.
\end{abstract}

Keywords: China Z Index (CZI), Kriging, Meteorological Drought, Southern Oscillation Index (SOI), Standardized Precipitation Index (SPI)

Abstrak: Kabupaten Blitar merupakan salah satu daerah yang rawan terjadi kekeringan, salah satunya yaitu DAS Lekso. Kekeringan yang terjadi di Kabupaten Blitar disebabkan oleh minimnya intensitas curah hujan yang turun, maka dari itu dibutuhkan upaya awal untuk memitigasi kekeringan meteorologi dengan cara memantau dan menganalisis kekeringan yang terjadi pada lokasi studi. Metode yang digunakan dalam menganalisis kekeringan yaitu metode Standardized Precipitation Index (SPI)) dan metode China Z Index (CZI) yang kemudian dibandingkan dengan data Southern Oscillation Index (SOI). Hasil indeks kekeringan kedua metode yang telah dikomparasi dengan data SOI akan digunakan sebagai penggambaran peta sebaran kekeringan menggunakan Sistem Informasi Geografis (SIG) dengan interpolasi Kriging. Pada hasil analisa perbandingan indeks kekeringan dengan data SOI bulanan didapatkan hasil persentase pendekatan metode CZI sebesar $57.45 \%$ dan metode SPI sebesar $42.55 \%$. Pada perbandingan indeks kekeringan dengan SOI rerata tahunan didapatkan persentase metode CZI sebesar 63\% dan metode SPI sebesar 
60\%. Pada hasil analisa korelasi indeks kekeringan yang dikomparasi dengan data hujan didapatkan nilai korelasi metode CZI memiliki tingkat hubungan korelasi mendekati positif sempurna dan metode SPI memiliki korelasi yang cukup. Sehingga metode CZI dipilih sebagai penggambaran peta sebaran kekeringan menggunakan interpolasi kriging yang kemudian didapatkan desa-desa yang terdampak kekeringan di Kabupaten Blitar khusunya di DAS Lekso.

Kata kunci: China Z Index (CZI), Kekeringan Meteorologi, Kriging, Southern Oscillation Index (SOI), Standardized Precipitation Index (SPI)

\section{Pendahuluan}

Bencana kekeringan merupakan suatu masalah yang dihadapi oleh hampir setiap negara di dunia walaupun tingkat kekeringan pada setiap wilayah berbeda. Di Indonesia sendiri kekeringan merupakan bencana alam yang rutin terjadi setiap tahunnya. Pada saat kekeringan melanda suatu wilayah, seringkali kurang disadari oleh masyarakat sekitar karena dampaknya belum dirasakan. Hal tersebut terjadi karena kurangnya informasi mengenai awal, akhir dan besarnya kekeringan yang seharusnya dapat dihitung seperti halnya banjir karena kekeringan meteorologi yang sepenuhnya berasal dari curah hujan. Kekeringan sulit diprediksi datangnya daripada fenomena-fenomena yang lain [1]. Kekeringan meteorologi berdasarkan data curah hujan memberikan gambaran dan pemahaman tentang karakteristik kekeringan di seluruh wilayah studi [2]. Analisa kekeringan meteorologi biasanya menggunakan data curah hujan bulanan, mengingat basis bulanan merupakan periode yang umum digunakan dalam studi penerapan sumber daya air [2]. Selain itu, curah hujan bulanan memberikan hasil yang relatif konsisten dan stabil, sehingga lebih sesuai untuk analisa kekeringan [2]. Kabupaten Blitar telah memetakan wilayah-wilayah yang terdampak kekeringan yaitu terdapat di 5 kecamatan dan 19 desa yang setiap tahunnya mengalam kekeringan [3]. Saat musim kemarau tiba, BPBD Kabupaten Blitar kerap mensuplai air ke wilayah tersebut karena minimnya intensitas curah hujan. Ditambah pula dengan wilayah perbukitan di Kabupaten Blitar banyak yang gundul sehingga memepengaruhi perubahan fungsi lahan dan pola tata tanam sehingga disinyalir sebagai penyumbang makin menyusutnya debit air di beberapa sungai salah satunya yaitu DAS Lekso.

Metode yang pernah digunakan dalam beberapa studi mengenai kekeringan meteorologis yaitu metode Standardized Precipitation Index (SPI) yang dikomparasi dengan metode China Z Index (CZI) dan metode lainnya seperti Decile Index (DI), Percent of Normal Index (PNI) yang diterapkan di Iran [4]. Penelitian lain juga mengkomparasi metode SPI dengan metode Effective Drought Index (EDI) [5]. Metode Standardized Precipitation Index (SPI) dipilih karena perhitungan yang sederhana serta metode ini sudah banyak digunakan di berbagai lokasi kekeringan sedangkan metode China $Z$ Index (CZI) dipilih karena perhitungannya yang lebih sederhana daripada metode SPI serta metode CZI lebih fleksibel untuk daerah di mana data curah hujan sering tidak lengkap atau data hujan yang hilang [6].

Analisa kekeringan meteorologi seharusnya dapat dihitung dan dijadikan dasar perkiraan dampak yang mungkin akan terjadi sehingga upaya mitigasi dapat dilaksanakan secepat mungkin jauh sebelum dampak terjadi. Oleh karena itu untuk menanggulangi bencana kekeringan, maka diperlukan analisa terhadap indeks kekeringan sebagai acuan dalam upaya penanggulangan bencana di wilayah tersebut serta memperkecil bencana yang terjadi. Dengan adanya studi perbandingan menggunakan kedua metode indeks kekeringan tersebut, diharapkan hasil studi ini dapat digunakan sebagai referensi dalam menentukan masalah-masalah bencana kekeringan di DAS Lekso dan dapat dijadikan sebagai alat peringatan (warning system) setiap tahunnya 


\section{Bahan dan Metode}

\subsection{Bahan}

\section{A. Lokasi Studi}

Lokasi studi ini berlokasi di Kabupaten Blitar dengan titik koordinat $114^{\circ} 40^{\prime}$ s/d $112^{\circ} 10^{\prime}$ Bujur Timur dan $07^{\circ} 58^{\prime} \mathrm{s} / \mathrm{d} 08^{\circ} 9^{\prime} 5^{\prime \prime}$ Lintang Selatan. Pada penelitian ini lokasi yang digunakan yaitu DAS Lekso dimana terdapat lima stasiun hujan yaitu stasiun hujan Bantaran, stasiun hujan Kaulon, stasiun hujan Wlingi, stasiun hujan Semen, stasiun hujan Ngadirenggo.

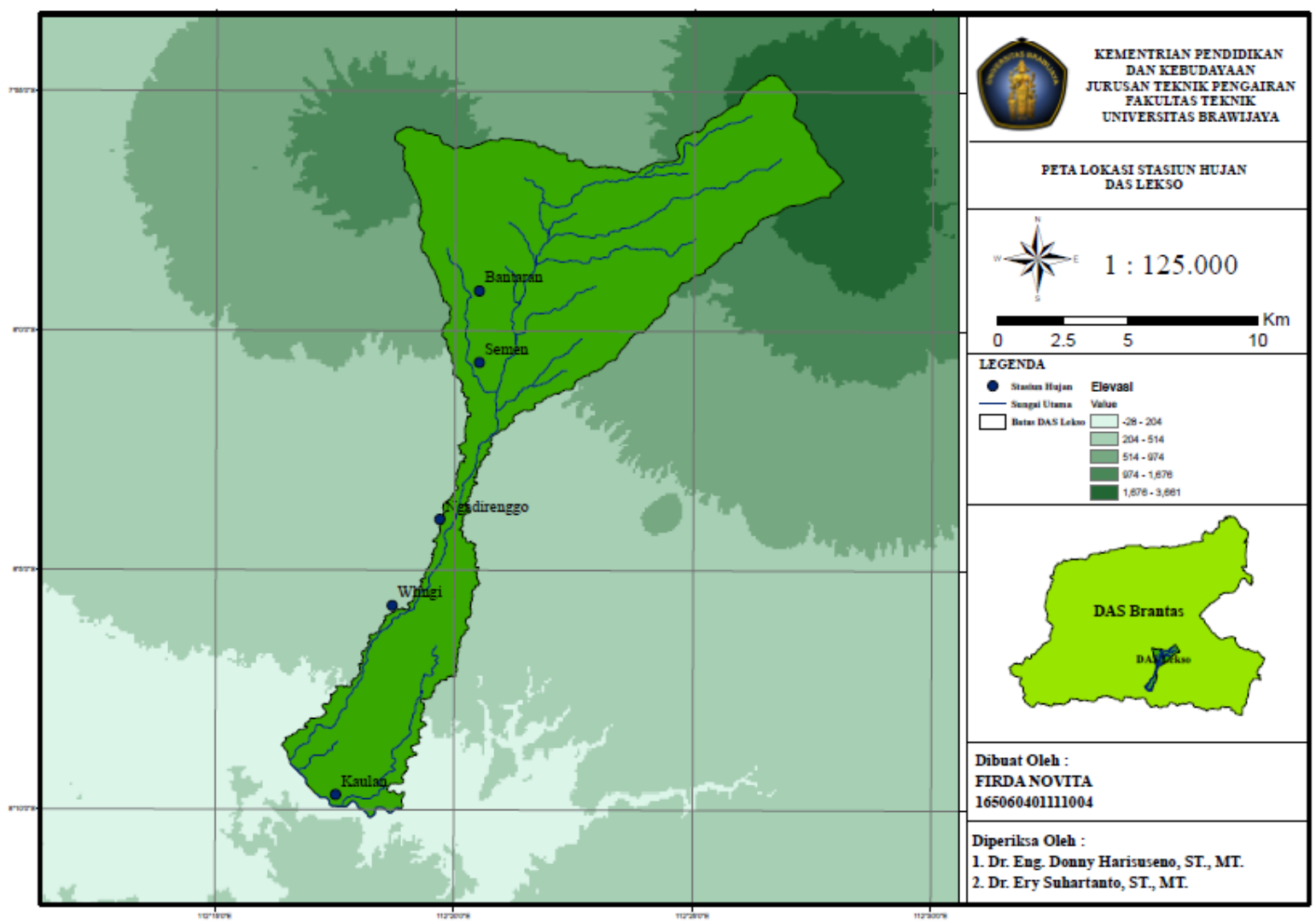

Gambar 1. Peta Lokasi Stasiun Hujan DAS Lekso

B. Data Penelitian

Dalam studi ini dibutuhkan data-data sekunder guna menunjang analisa yang akan dilakukan, berikut merupakan data yang dibutuhkan antara lain:

- Data curah hujan bulanan tahun 1999 - 2018

- Data Indeks Osilasi Selatan (SOI) bulanan tahun 1999 -2018

- Peta batas DAS Lekso

- Peta administrasi Kabupaten Blitar

- Peta Lokasi Stasiun Hujan

\subsection{Metode}

Metode studi disusun secara sistematis sehingga mempermudah dalam penyelesaiannya. Berikut merupakan tahapan penelitian pada studi ini: 


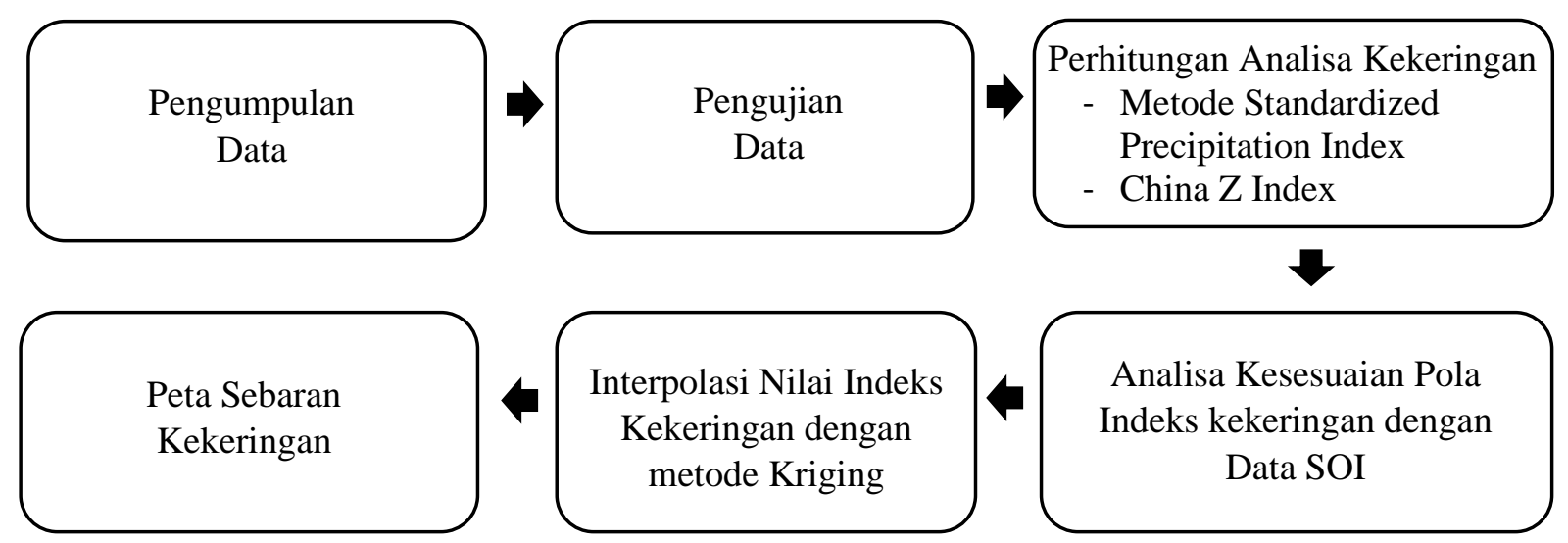

Pada tahapan penelitian diatas analisa yang pertama dilakukan yaitu melakukan pengumpulan data yang berupa data curah hujan hujan selama 20 tahun, peta administrasi kabupaten blitar, peta batas DAS Lekso, serta data koordinat stasiun hujan. Setelah didapatkan data tersebut kemudian dilanjutkan dengan menguji data tersebut agar mengetahui apakah data yang digunakan layak untuk analisa pada studi ini. Pengujian data yang dilakukan yaitu menggunakan Uji Konsistensi dan Uji Stasioner. Jika data yang diuji layak dan memenuhi kriteria, maka dilanjutkan untuk melakukan perhitungan analisa kekeringan menggunakan metode Standardized Precipitation Index (SPI) dan metode China Z Index (CZI). Setelah didapatkan hasil dari indeks kekeringan kedua metode, selanjutnya melakukan perhitungan analisa kesesuaian pola antara hasil indeks kekeringan metode Standardized Precipitation Index (SPI) dan metode China Z Index (CZI) yang dikomparasi dengan Data Southern Oscillation Index (SOI). Setelah mengetahui metode mana yang memiliki kesesuaian yang baik dengan data SOI kemudian dilakukan penggambaran peta sebaran kekeringannya dengan metode interpolasi Kriging menggunakan program Arcgis 10.4.1. Kemudian didapatkan peta sebaran kekeringan dengan daerah daerah terdampak kekeringan sesuai dengan metode interpolasi Kriging.

Dari analisa yang dilakukan melalui pembahasan seperti yang telah dijelaskan diatas didapatkan rancangan hasil studi sebagai berikut :

1. Mengetahui nilai Indeks kekeringan yang terjadi di DAS Lekso.

2. Mengetahui keterkaitan atau pengaruh SOI dengan kondosi asli di lokasi studi.

3. Mengetahui peta sebaran kekeringan di DAS Lekso dan dapat mengetahui perbandingan nilai indeks kekeringan dengan menggunakan metode Standardized Precipitation Index (SPI) dan China Z Index (CZI) di DAS Lekso.

\subsection{Persamaan}

\subsubsection{Metode Standardized Precipitation Index (SPI)}

Metode Standardized Precipitation Index (SPI) merupakan model untuk mengukur kekurangan atau defisit curah hujan pada berbagai periode berdasarkan kondisi normalnya. Metode Standardized Precipitation Index (SPI) dikembangkan oleh McKee pada tahun 1993 dan digunakan sebagai salah satu indeks untuk memantau kekeringan di seluruh Amerika Serikat [7]. SPI memiliki beberapa kelebihan dan kelemahan. Kelebihan dari SPI diantaranya adalah bersifat fleksibel karena dapat dihitung pada beberapa rentang waktu,dapat digunakan untuk memberikan peringatan dini terhadap kekringan, dapat digunakan untuk menilai tingkat keparagan kekeringan, bersifat spapsial konsisten sehingga dapat digunakan untuk membandingkan antara lokasi yang berbeda serta dapat digunakan sebagai dasar dalam pengambilan keputusan. Sementara itu, kelemahan SPI adalah penentuan kekeringan hanya didasarkan pada cura hujan dan tidak memperhitungkan neraca air [8]. Metode Standardized Precipitation Index (SPI) memiliki kriteria nilai indeks kekeringan yang diklasifikasikan sebagai berikut: 
Tabel 1: Klasifikasi Kekeringan SPI

\begin{tabular}{cc}
\hline Klasifikasi & Nilai SPI \\
\hline \hline Amat Sangat Basah & $>2,00$ \\
\hline Sangat Basah & $1,50-1,99$ \\
\hline Cukup Basah & $1,00-1,49$ \\
\hline Mendekati Normal & $(-0,99)-0,99$ \\
\hline Cukup Kering & $(-1,00)-(-1,49)$ \\
\hline Sangat Kering & $(-1,50)-(-1,99)$ \\
\hline Amat Sangat Kering & $<(-2,00)$ \\
\hline
\end{tabular}

Perhitungan nilai SPI berdasarkan jumlah sebaran gamma yang didefinisikan sebagai fungsi frekuensi atau peluang kejadian sebagai berikut :

$$
G(x)=\int_{0}^{x} g(x)=\frac{1}{\beta^{\alpha} \mathrm{T}(a)} \int_{0}^{x} t^{a-1} e^{-x / \beta} d x
$$

Pers. 1

Nilai $\alpha$ dan $\beta$ diestimasi untuk setiap stasiun hujan dengan menggunakan rumus sebagai berikut :

$$
\begin{aligned}
& \alpha=\frac{1}{4 A}\left(1+\sqrt{1+\frac{4 A}{3}}\right) \\
& A=\operatorname{In}(\bar{x})-\frac{\sum \operatorname{In}(x)}{n}
\end{aligned}
$$

Pers. 2

Pers. 3

Atau:

$$
\begin{aligned}
& \alpha=\alpha=\frac{\bar{x}^{2}}{s^{2}} \\
& \beta=\frac{\bar{x}}{\alpha}
\end{aligned}
$$

Pers. 4

Pers. 5

Untuk $\mathrm{x}>0$

Untuk $\mathrm{x}=0$ maka nilai $\mathrm{G}(\mathrm{x})$ menjadi:

$$
H(x)=q+(1-q) \cdot \mathrm{G}(\mathrm{x})
$$

Pers. 6

Nilai SPI merupakan transformasi dari distribusi gamma $(\mathrm{G}(\mathrm{x}))$ menjadi standart normal dengan rata rata 0 (nol) dan perbedaan 1 , atau menggunakan rumusan dibawah ini:

$$
\begin{array}{ll}
Z=S P I=-\left(t-\frac{C_{0}+C_{1}+C_{2} t^{2}}{1+d_{1} t+d_{2} t^{2}+d_{3}^{3}}\right) \text { untuk } 0<\mathrm{H}(\mathrm{x}) \leq 0,5 & \text { Pers. } 7 \\
Z=S P I=+\left(t-\frac{C_{0}+C_{1}+C_{2} t^{2}}{1+d_{1} t+d_{2} t^{2}+d_{3}^{3}}\right) \text { untuk } 0,5<\mathrm{H}(\mathrm{x}) \leq 1,0 & \text { Pers. } 8
\end{array}
$$


Dengan:

$$
\begin{array}{ll}
t=\sqrt{\operatorname{In}\left(\frac{1}{(H(x))^{2}}\right)} \text { Untuk } 0<\mathrm{H}(\mathrm{x}) \leq 0,5 & \text { Pers. } 9 \\
t=\sqrt{\operatorname{In}\left(\frac{1}{(1,0-H(x))^{2}}\right)} \text { untuk } 0<\mathrm{H}(\mathrm{x}) \leq 1,0 & \text { Pers. } 10
\end{array}
$$

\subsubsection{Metode China Z Index (CZI)}

Dikembangkan di Cina, CZI dibangun berdasarkan kemudahan perhitungan yang disediakan oleh SPI dan meningkatkannya dengan membuat perhitungan lebih mudah bagi pengguna. China $Z$ Index (CZI) dapat digunakan untuk mengidentifikasi dan memantau periode kekeringan di berbagai skala waktu. China Z Index (CZI) mirip dengan SPI karena parameter curah hujan yang digunakan untuk menentukan periode basah dan kering. Indeks ini pertama kali digunakan dan dikembangkan pada tahun 1995 oleh Pusat Iklim Nasional China.

Hasil studi menunjukkan bahwa CZI dapat memberikan hasil yang mirip dengan SPI untuk semua skala waktu [1]. Dengan asumsi bahwa data curah hujan mematuhi distribusi Pearson Type III. Akan tetapi, banyak faktor yang mempengaruhi hasil dari indeks kekeringan metode China Z Index, salah satunya yaitu wilayah iklim yang berbeda sehingga menyebabkan ketidaksesuaian hasil mengingat penelitian tersebut dilakukan di China [9]. Faktor lain dapat juga dipengaruhi oleh ketidakkonsistenan curah hujan yang disesbakan oleh fenomena perubahan iklim dan perubahan lingkungan DAS [9]. CZI dihitung sebagai berikut:

$$
\begin{aligned}
& Z_{i j}=\frac{6}{C_{s i}}\left(\frac{C_{s i}}{2} \varphi_{i j}+1\right)^{1 / 3}-\frac{6}{C_{s i}}+\frac{C_{s i}}{6} \\
& C_{s i}=\frac{\sum_{j=1}^{n}\left(x_{i j}-\bar{x}_{i}\right)^{3}}{n^{*} \sigma_{i}^{3}} \\
& \varphi_{i j}=\frac{X_{i j}-\bar{x}_{i}}{\sigma_{i}}
\end{aligned}
$$

Pers. 11

Pers. 12

Pers. 13

Dimana Zij adalah CZI, i adalah skala waktu yang bisa sama dengan 1, 2, 3, ., 72 bulan, dan $\mathrm{j}$ adalah bulan saat ini. Dalam CZI yang digunakan oleh NCC, parameter i tidak digunakan karena hanya nilai Z untuk skala waktu 1 bulan dihitung. Dalam studi ini, kami memperluas CZI untuk memasukkan beberapa skala waktu ini. Untuk klasifikasi indeks kekeringan metode China Z Index (CZI) sama dengan klasifikasi metode Standardized Precipitation Index (SPI) yang dapat dilihat pada tabel 1.

\subsubsection{Southern Oscillation Index (SOI)}

Southern Oscillation Index (SOI) adalah perbedaan antara tekanan udara permukaan (msl) di daerah Pasifik Timur yang diukur di Tahiti, dengan tekanan udara permukaan (msl) di daerah Pasifik Barat (Indo-Australia) yang diukur di Darwin, Australia [10]. Diperkirakan terjadinya El Nino jika nilai SOI negatif selama periode yang cukup lama (minimal 3 bulan). Nilai SOI dihitung menggunakan formula yang dirumuskan oleh Troup [11]. 


\section{Hasil dan Pembahasan}

\subsection{Hasil Pengujian Kualitas Data Hujan}

Berdasarkan hasil pengujian data hujan menggunakan uji konsistensi kurva massa ganda dan uji RAPS 5 stasiun hujan pada DAS Lekso didapatkan 3 stasiun hujan yang menggunakan metode kurva massa ganda tidak ditemukan adanya penyimpangan dengan sudut yang sudah ditentukan sehingga memiliki data yang konsisten, sedangkan 2 stasiun hujan yang menggunakan metode RAPS didapatkan hasil yang konsisten sehingga dapat melanjutkan ke tahap pengujian kualitas data hujan menggunakan uji stasioner. Berdasarkan uji stasioner menggunakan Uji $\mathrm{F}$ dan Uji $\mathrm{T}$ pada lima stasiun hujan menggunakan derajat kepercayaan 5\% dengan pengujian dua arah didapatkan kelima stasiun hujan memiliki hipotesa nol yang bersifat homogen dan stasioner. Artinya seluruh data hujan di DAS Lekso merupakan data yang stabil terhadap nilai rata-rata dan nilai variannya.

\subsection{Indeks Kekeringan Metode Standardized Precipitation Index (SPI)}

Berdasarkan hasil indeks kekeringan metode SPI yang dihitung pada skala waktu 1, 3, 6, dan 12 Bulanan didapatkan hasil sebagai berikut:

Tabel 2: Rekapitulasi Jumlah Kejadian Kekeringan dan Nilai Indeks Minimum SPI

\begin{tabular}{|c|c|c|c|c|c|c|c|c|}
\hline \multirow{2}{*}{ No } & \multirow{2}{*}{$\begin{array}{l}\text { Stasiun } \\
\text { Hujan }\end{array}$} & \multicolumn{5}{|c|}{ Kejadian Kekeringan } & \multirow{2}{*}{$\begin{array}{c}\text { Jumlah } \\
\text { Kejadian } \\
\text { Kekeringan } \\
\end{array}$} & \multirow{2}{*}{$\begin{array}{c}\text { Nilai } \\
\text { Indeks } \\
\text { Minimum }\end{array}$} \\
\hline & & Bantaran & Kaulon & Semen & Wlingi & Ngadirenggoo & & \\
\hline 1 & 1 Bulanan & 20 & 29 & 20 & 31 & 23 & 123 & $-4,49$ \\
\hline 2 & 3 Bulanan & 29 & 35 & 29 & 36 & 29 & 158 & $-3,61$ \\
\hline 3 & 6 Bulanan & 23 & 33 & 21 & 32 & 32 & 141 & $-3,34$ \\
\hline 4 & 12 Bulanan & 17 & 17 & 25 & 29 & 24 & 112 & $-2,61$ \\
\hline
\end{tabular}

Pada tabel 2 didapatkan jumlah kejadian kekeringan metode SPI terbanyak yaitu pada periode defisit 3 bulanan yaitu sebesar 158 kejadian dengan intensitas kering hingga amat sangat kering, sedangkan nilai indeks kekeringan minimum terjadi pada periode defisit 1 bulanan dengan nilai indeks minimum sebesar $-4,49$, hal tersebut dapat dipengaruhi oleh berbagai macam faktor salah satunya dikarenakan periode defisit 1 bulanan masih sangat fluktuatif untuk pembacaan klasifikasi kering dan basahnya.

\subsection{Indeks Kekeringan Metode China Z Index (CZI)}

Berdasarkan hasil indeks kekeringan metode CZI yang dihitung pada skala waktu 1, 3, 6, dan 12 Bulanan didapatkan hasil sebagai berikut:

Tabel 3: Rekapitulasi Jumlah Kejadian Kekeringan dan Nilai Indeks Minimum CZI

\begin{tabular}{|c|c|c|c|c|c|c|c|c|}
\hline \multirow{2}{*}{ No } & \multirow{2}{*}{$\begin{array}{c}\text { Stasiun } \\
\text { Hujan }\end{array}$} & \multicolumn{5}{|c|}{ Kejadian Kekeringan } & \multirow{2}{*}{$\begin{array}{c}\text { Jumlah } \\
\text { Kejadian } \\
\text { Kekeringan } \\
\end{array}$} & \multirow{2}{*}{$\begin{array}{c}\text { Nilai } \\
\text { Indeks } \\
\text { Minimum }\end{array}$} \\
\hline & & Bantaran & Kaulon & Semen & Wlingi & Ngadirenggo & & \\
\hline 1 & 1 Bulanan & 73 & 67 & 64 & 59 & 69 & 332 & $-7,46$ \\
\hline 2 & 3 Bulanan & 56 & 63 & 63 & 67 & 61 & 310 & $-6,26$ \\
\hline 3 & 6 Bulanan & 49 & 54 & 54 & 58 & 56 & 271 & $-6,43$ \\
\hline 4 & 12 Bulanan & 44 & 53 & 44 & 59 & 54 & 254 & $-8,32$ \\
\hline
\end{tabular}

Pada tabel 3 didapatkan jumlah kejadian kekeringan metode CZI terbanyak yaitu pada periode defisit 1 bulanan yaitu sebesar 332 kejadian dengan intensitas kering hingga amat kering, sedangkan 
nilai indeks kekeringan minimum terjadi pada periode defisit 12 bulanan dengan nilai indeks minimum sebesar $-8,32$, hal tersebut dikarenakan pada periode defisit 12 bulanan merupakan akumulasi hujan bulanan yang akan memberikan dampak pada hasil indeks kekeringan sehingga semakin bertambahnya periode defisit akan menghasilkan indeks kekeringan yang stabil untuk pembacaan klasifikasi kering dan basahnya.

\subsection{Perbandingan Hasil Analisa Kekeringan dengan Data SOI bulanan}

Perbandingan analisa kekeringan dengan SOI dilakukan untuk mengetahui apakah kekeringan yang terjadi di DAS Lekso dipengaruhi oleh fenomena ENSO. Hasil analisa yang dilakukan yaitu dengan melakukan perbandingan persentase kesesuaian dan persentase kedekatan dari hasil klasifikasi yang sudah didapatkan.

Tabel 4: Rekapitulasi Persentase Pendekatan Indeks Kekeringan \& Data SOI Bulanan

\begin{tabular}{cccc}
\hline \multirow{2}{*}{ No } & \multirow{2}{*}{ Pos Hujan } & $\begin{array}{c}\text { Persentase Pendekatan SPI \& } \\
\text { Data SOI }\end{array}$ & $\begin{array}{c}\text { Persentase Pendekatan CZI \& } \\
\text { Data SOI }\end{array}$ \\
\hline \hline 1 & Bantaran & $51,22 \%$ & $48,78 \%$ \\
2 & Kaulon & $36,36 \%$ & $63,64 \%$ \\
3 & Semen & $42,31 \%$ & $57,69 \%$ \\
4 & Wlingi & $42,86 \%$ & $57,14 \%$ \\
5 & Ngadirenggo & $40,00 \%$ & $60,00 \%$ \\
\hline \hline
\end{tabular}

Berdasarkan rekapitulasi pada tabel 4 didapatkan persentase pendekatan indeks kekeringan metode China Z Index (CZI) memiliki persentase pendekatan sebesar 57,45\% dengan Data SOI bulanan, sedangkan metode Standardized Precipitation Index (SPI) memiliki persentase pendekatan sebesar $42,55 \%$. Artinya metode CZI lebih kecil fluktuatifnya daripada metode SPI untuk membaca status kering dan basah.

\subsection{Perbandingan Hasil Analisa Kekeringan dengan Data SOI Rerata Tahunan}

Perbandingan analisa kekeringan dengan SOI tahunan dilakukan untuk lebih menguatkan persentase kesesuaian antara metode China Z Index (CZI) dan metode Standardized Precipitation Index (SPI) dengan Data Southern Oscillation Index (SOI), Maka selanjutnya dilakukan analisa perbandingan hasil analisa dengan data SOI rerata tahunan dengan membandingan nilai surplus dan defisit pada masing-masing metode.
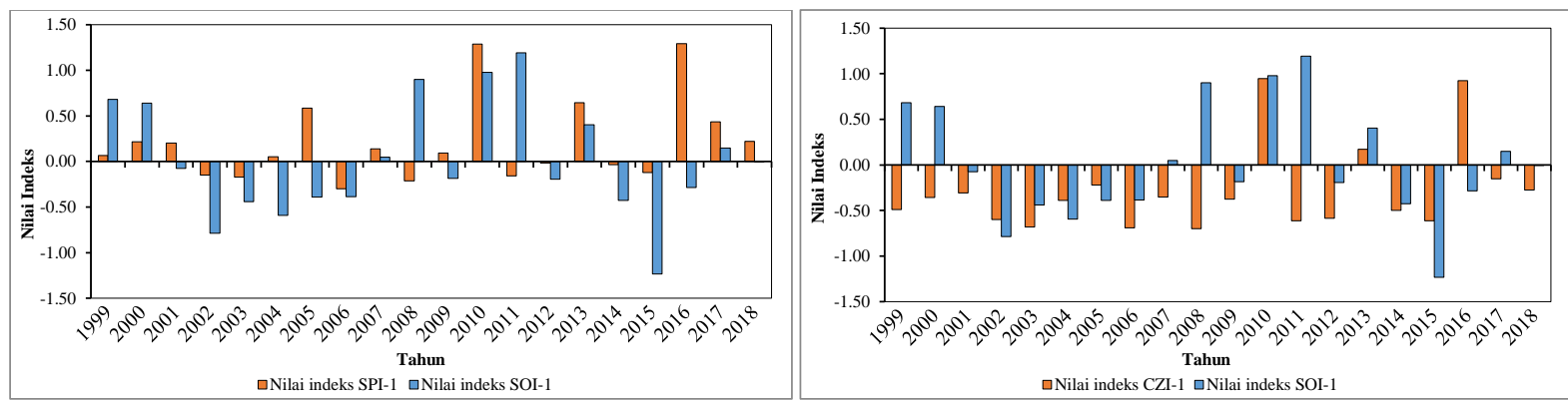

\section{Gambar 3: Hasil Indeks Kekeringan dengan SOI Rerata Tahunan Stasiun Hujan Bantaran Periode} Defisit 1 Bulanan

Dari grafik surplus dan defisit yang tertera pada gambar 3 dapat diketahui bahwa pada metode SPI memiliki 8 tahun pengamatan yang tidak sesuai dengan data SOI yaitu pada tahun 2001, 2004, 2005, 2008, 2009, 2011, 2016 dan 2018. Sedangkan pada metode CZI memiliki 7 tahun pengamatan yang tidak sesuai dengan data SOI yaitu pada tahun 1999, 2000, 2007, 2008, 2011, 2016, dan 2017. Setelah 
mengetahui grafik surplus dan defisit serta tahun pengamatan yang tidak sesuai, kemudian dihitung persen kesesusaian indeks kekeringan dengan nilai indeks osilasi selatan (SOI)

Tabel 5: Rekapitulasi Persentase Kesesuaian Indeks Kekeringan \& Data SOI Rerata Tahunan

\begin{tabular}{clcclc}
\hline & \multicolumn{2}{c}{ SPI } & \multicolumn{2}{c}{ CZI } \\
\hline No. & Nama Stasiun & Persentase & No. & Nama Stasiun & Persentase \\
\hline \hline 1. & Bantaran & $60 \%$ & 1. & Bantaran & $65 \%$ \\
2. & Kaulon & $70 \%$ & 2. & Kaulon & $60 \%$ \\
3. & Semen & $45 \%$ & 3. & Semen & $65 \%$ \\
4. & Wlingi & $75 \%$ & 4. & Wlingi & $65 \%$ \\
5. & Ngadirenggo & $50 \%$ & 5. & Ngadirenggo & $60 \%$ \\
\hline & Rerata & $60 \%$ & & Rerata & $63 \%$ \\
\hline
\end{tabular}

Setelah menghitung persentase kedua metode dengan Data SOI rerata tahunan dapat disimpulkan bahwa hasil indeks kekeringan yang tidak sesuai dengan data SOI dikarenakan parameter klimatologi yang sangat beragam sehingga menyebabkan perbedaan hasil antara indeks kekeringan kedua metode dengan SOI yang mana jika metode SPI dan CZI hanya menggunakan parameter curah hujan sedangkan SOI menggunakan perbedaan tekanan permukaan laut antara Tahiti dan Darwin-Australia yang sangat mempengaruhi iklim di Indonesia atau siklus ENSO. Maka didapatkan kesimpulan bahwa persentase tertinggi atau memiliki kesesuaian yang tinggi dengan data SOI yaitu metode China $Z$ Index (CZI) dengan persentase rata-rata $63 \%$.

\subsection{Analisa Korelasi}

Analisa Korelasi digunakan untuk menunjukkan kuatnya suatu hubungan antara dua variabel atau lebih. Dalam studi ini analisa korelasi digunakan untuk mengetahui kuatnya suatu hubungan antara Indeks Kekeringan Meteorologi dengan Nilai SOI dan Data Hujan.

\subsubsection{Analisa Korelasi Indeks Kekeringan dengan Data SOI}

Analisa korelasi indeks kekeringan dengan data SOI digunakan untuk memastikan metode mana yang sesuai dengan data SOI dan memiliki hubungan dengan fenomena El Nino Southern Oscillation Index (ENSO).
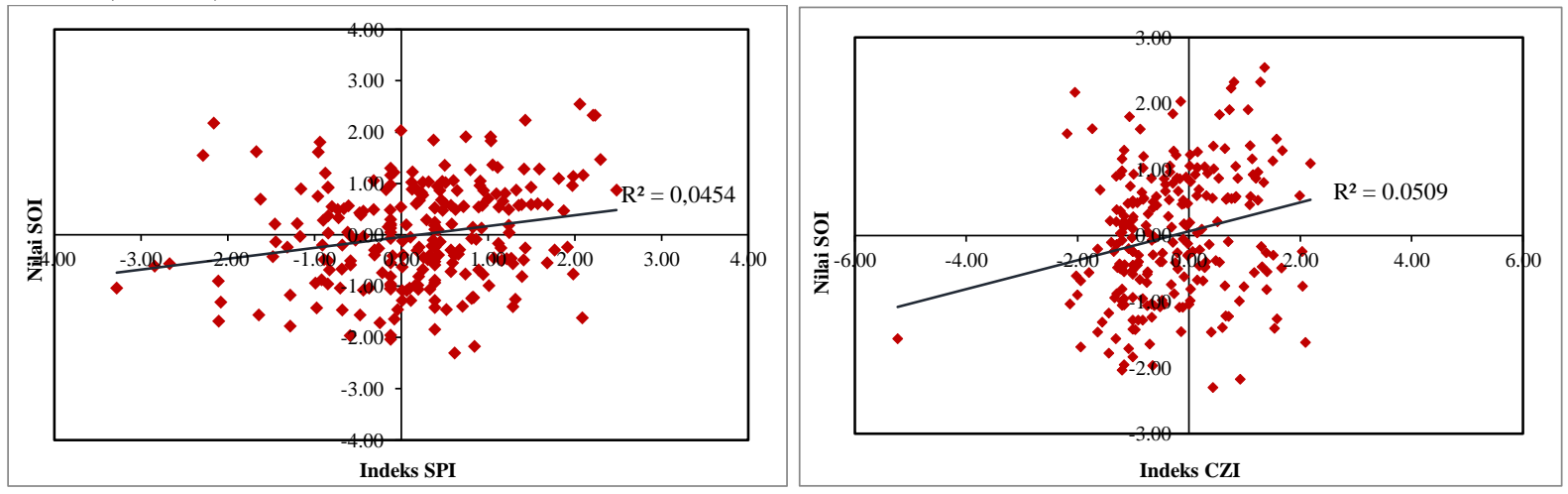

Gambar 4: Hasil Analisa Korelasi Indeks Kekeringan dengan SOI Stasiun Hujan Bantaran Periode Defisit 1 Bulanan

Berdasarkan gambar 4 didapatkan nilai $\mathrm{R}^{2}$ (nilai determinasi) hasil dari scatter plotter yaitu sebesar 0,0454 untuk metode SPI, dan 0,0509 untuk metode CZI. Setelah didapatkan nilai determinasi $\left(\mathbf{R}^{2}\right)$ kemudian dicari analisa korelasinya $(\mathrm{R})$ dengan cara mengakarkan nilai $\mathrm{R}^{2}$ yang sudah didapat dari gambar 4 dan didapatkan tingkat hubungan korelasi cukup yang menunjukkan lemahnya hubungan 
antara dua variabel. Sehingga dilakukan perbandingan analisa lanjutan dengan mengkorelasikan indeks kekeringan dengan data SOI.

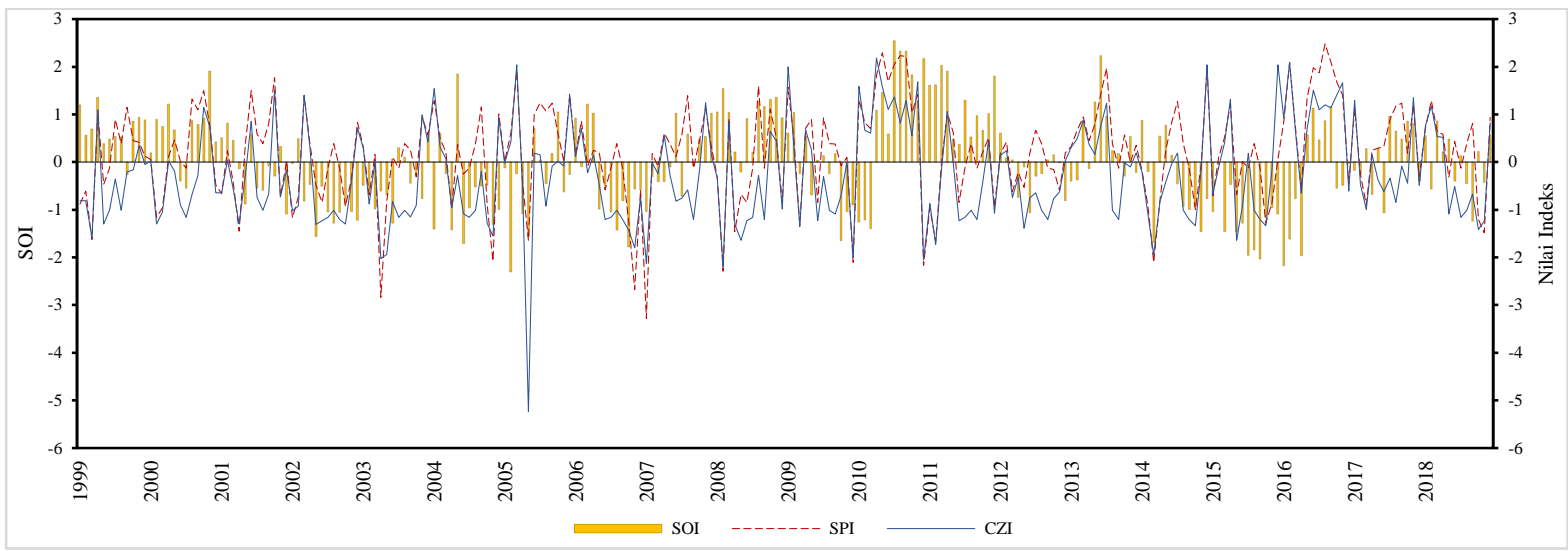

Gambar 5: Grafik Perbandingan Indeks Kekeringan dengan SOI Stasiun Hujan Bantaran Periode Defisit 1 Bulanan

Pada gambar 5 dapat dilihat bahwa metode Standardized Precipitation Index (SPI) dan China Z Index (CZI) memiliki pola yang hampir sama dengan data SOI, ketika pola SOI naik maka pola metode indeks kekeringan juga akan ikut naik begitupun sebaliknya. Akan tetapi dilihat dari grafik, masih sangat fluktuatif untuk rentang nilai antara kedua metode indeks kekeringan dengan data SOI, pada metode China Z Index (CZI) lebih besar pembacaan status kekeringannya.

\subsubsection{Analisa Korelasi Indeks Kekeringan dengan Data Hujan}

Analisa korelasi indeks kekeringan dengan data hujan digunakan untuk mengetahui seberapa dekat hubungan antara hasil analisa menggunakan metode SPI dengan data curah hujan yang ada dilapangan.
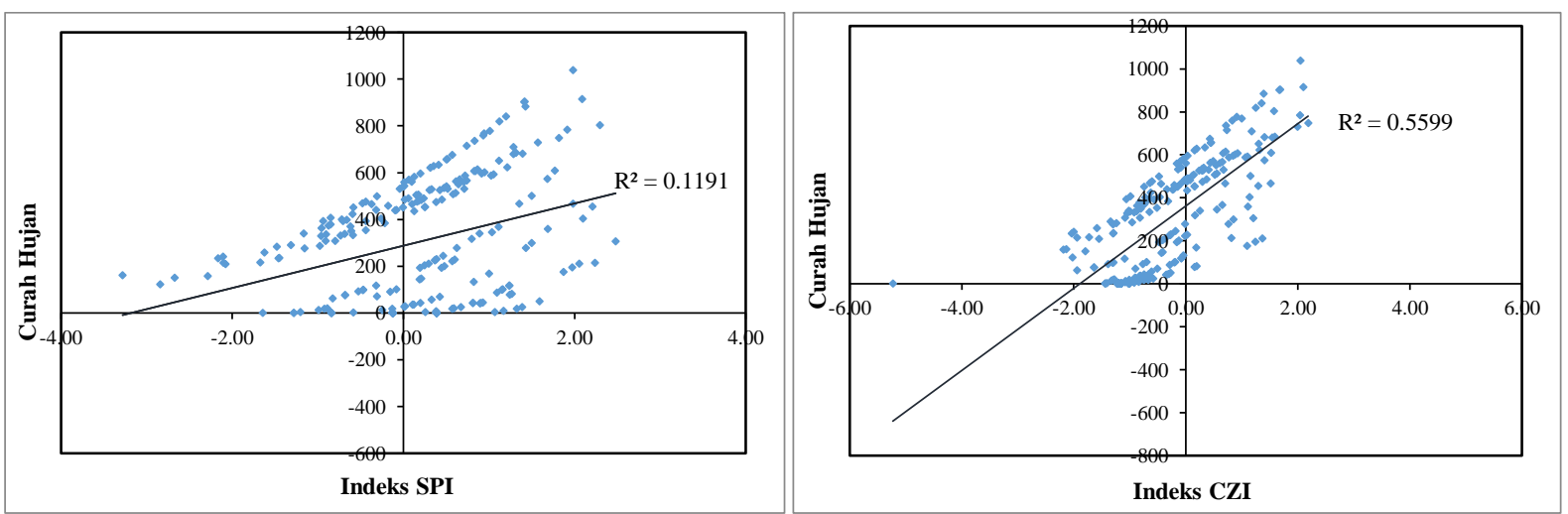

\section{Gambar 6: Hasil Analisa Korelasi Indeks Kekeringan dengan Data Hujan Stasiun Hujan Bantaran Periode Defisit 1 Bulanan}

Berdasarkan gambar 6 didapatkan nilai $\mathrm{R}^{2}$ (nilai determinasi) hasil dari scatter plotter yaitu sebesar 0,1191 untuk metode Standardized Precipitation Index (SPI), dan 0,5599 untuk metode China Z Index (CZI). Setelah didapatkan nilai determinasi $\left(\mathrm{R}^{2}\right)$ kemudian dicari analisa korelasinya $(\mathrm{R})$ dengan cara mengakarkan nilai $\mathrm{R}^{2}$ yang sudah didapat dari gambar 5 dan didapatkan hubungan korelasi kedua indeks kekeringan dengan data hujan. 
Tabel 6: Rekapitulasi Analisa Korelasi Indeks Kekeringan CZI dengan Data Hujan

\begin{tabular}{cccc}
\hline Nama Stasiun & $\begin{array}{c}\text { Koefisien } \\
\text { Deterinasi }\end{array}$ & $\begin{array}{c}\text { Koefisien } \\
\text { Korelasi }\end{array}$ & Hubungan \\
\hline \hline Bantaran & 0,560 & 0,748 & Korelasi Kuat \\
Kaulon & 0,581 & 0,762 & Korelasi Sangat Kuat \\
Semen & 0,604 & 0,777 & Korelasi Sangat Kuat \\
Wlingi & 0,437 & 0,661 & Korelasi Kuat \\
Ngadirenggo & 0,349 & 0,591 & Korelasi Kuat \\
\hline
\end{tabular}

Dapat dilihat pada tabel 3 tingkat hubungan korelasi terbesar yaitu stasiun hujan Semen dengan nilai determinasi $\left(R^{2}\right)$ 0,604 serta nilai korelasi (R) 0,777 dengan tingkat hubungan korelasi sangat kuat. Dapat disimpulkan bahwa korelasi metode CZI dengan data hujan memiliki tingkat hubungan yang kuat yang mana kedua variabel menunjukkan kesamaan waktu kejadian fenomena meteorologi yang dapat dijadikan acuan untuk pemilihan metode mana yang sesuai dengan kondisi di lapangan.

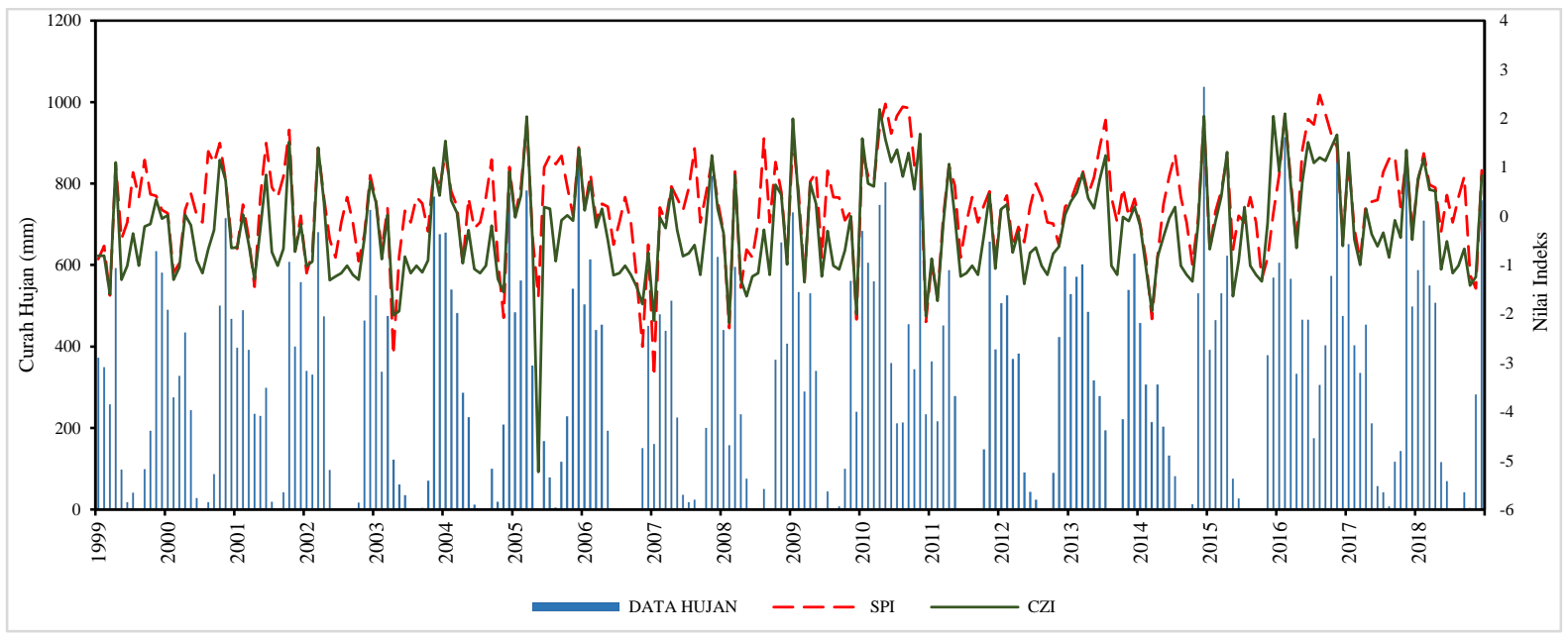

\section{Gambar 7 Grafik Perbandingan Indeks Kekeringan dengan Data Hujan Stasiun Hujan Bantaran Periode Defisit 1 Bulanan}

Pada gambar 7 dapat dilihat bahwa kedua metode indeks kekeringan memiliki pola yang hampir sama dengan data hujan yang ada di DAS Lekso. Ketika curah hujan tinggi maka nilai indeksnya akan naik dan menunjukkan klasifikasi basah, begitupun sebaliknya jika curah hujan rendah maka nilai indeksnya akan turun dan menunjukkan klasifikasi kering. Hal ini diperkuat dengan hasil analisa korelasi antara kedua metode dan data curah hujan memiliki tingkat hubungan yang kuat.

\subsection{Pemetaan Sebaran Kekeringan}

Penggambaran peta sebaran kekeringan yang ada di DAS Lekso dilakukan menggunakan Sistem Informasi Geografis (SIG) dengan metode interpolasi kriging. Metode China Z Index (CZI) dipilih untuk penggambaran peta sebaran kekeringan yang ada di DAS Lekso yang kemudian di overlay dengan batas administrasi yang ada di kabupaten blitar agar mendapatkan desa-desa yang terdampak kekeringan di setiap tahunnya. 


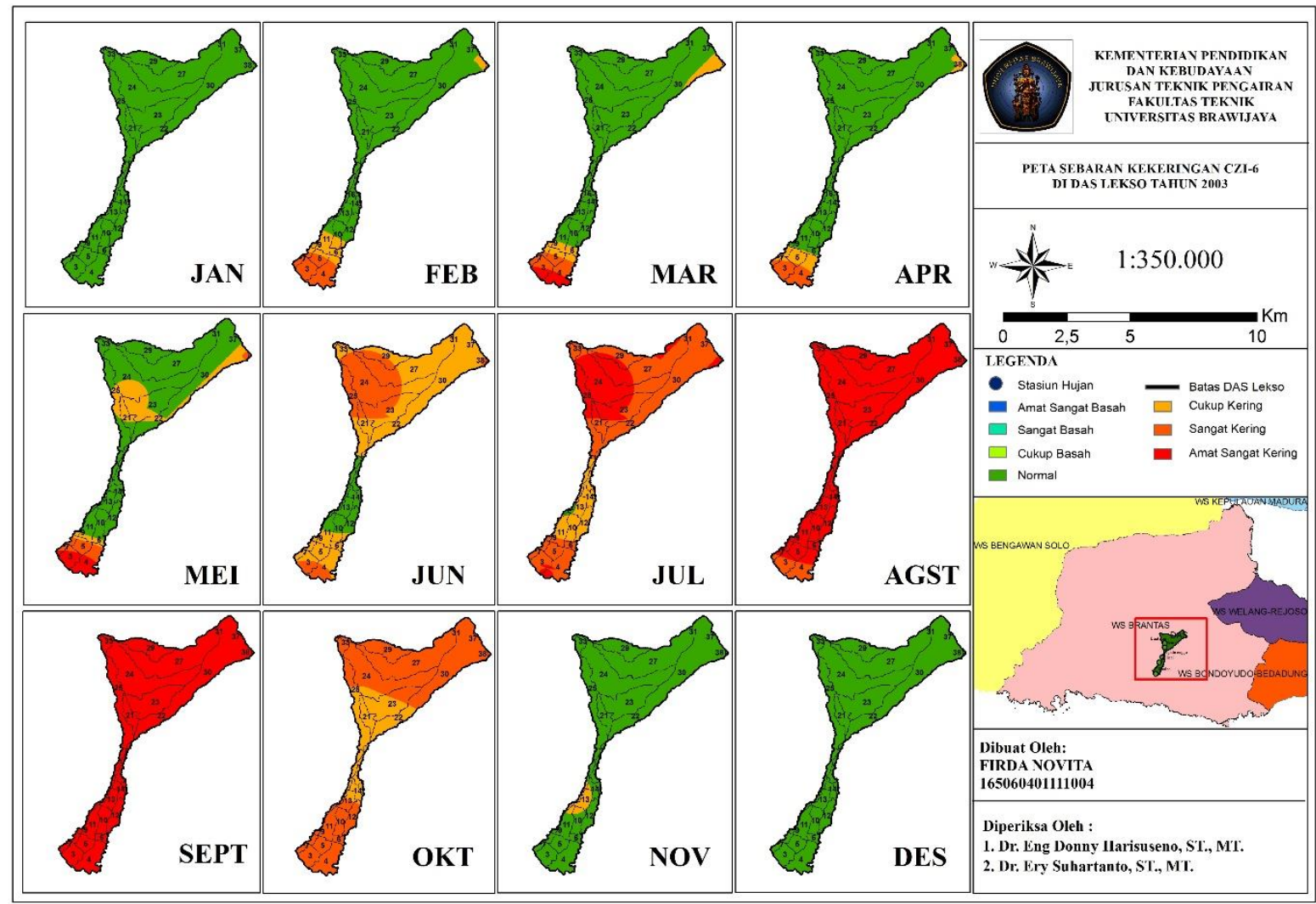

Gambar 8: Hasil Peta Sebaran Kekeringan Metode China Z Index Tahun 2003

Berdasarkan gambar 8 didapatkan hasil peta sebaran kekeringan metode China Z Index (CZI) yang paling sesuai yaitu pada periode defisit 6 bulanan. Dapat dilihat terdapat perbedaan kondisi kering dan basah berdasarkan warna pada peta. Hasil peta sebaran kekeringan menunjukkan kondisi kekeringan terparah biasanya terjadi pada bulan Juli - Oktober dengan intensitas kering hingga amat sangat kering. Sehingga dapat disimpulkan bahwa semakin besar periode defisit yang digunakan maka akan semakin stabil nilai indeks kekeringannya, hal tersebut dikarenakan jumlah akumulasi dari data curah hujan yang mengakibatkan kestabilan pada hasil indeks kekeringan pada metode China Z Index (CZI).

\section{Kesimpulan}

Dari analisa yang sudah dilakukan, maka didapatkan kesimpulan sebagai berikut:

a. Metode SPI menghasilkan nilai indeks kekeringan maksimum sebesar -4,491 pada periode defisit 1 bulanan pada stasiun hujan ngadirenggo tahun 2005, sedangkan Metode CZI menghasilkan indeks kekeringan minimum sebesar $-8,320$ pada periode defisit 12 pada stasiun hujan bantaran dengan intensitas amat sangat kering

b. Perbandingan metode SPI dan metode CZI dengan Data SOI didapatkan metode CZI memiliki hasil yang menunjukkan kesesuaian dengan hasil sebesar 57,45\%, sedangkan metode SPI memiliki kesesuaian sebesar $42,55 \%$.

c. Hasil peta sebaran kekeringan yang dipilih untuk penggambaran sebaran kekeringan di DAS Lekso yaitu metode CZI dengan periode defisit yang sesuai yaitu 6 bulanan yang mana periode defisit tersebut sama dengan kejadian siklum musim di Indonesia. 


\section{Daftar Pustaka}

[1] H. Wu, M. Hayes, A. Weiss and Q. Hu, "An evaluation of the Standardized Precipitation Index, the China-Z Index and the statistical Z-Score", International Journal of Climatology, vol. 21, no. 6, pp. 745-758, 2001. Available: 10.1002/joc.658.

[2] D. Harisuseno, "Comparative study of meteorological and hydrological drought characteristics in the Pekalen River basin, East Java, Indonesia", Journal of Water and Land Development. No. 45 (IV-VI) p. 29-41, 2020. DOI: 10.24425/jwld. 2020.133043.

[3] Indeks Informasi El-Nino dan IOD Dasarian I Januari 2020 | BMKG", BMKG | Badan Meteorologi, Klimatologi, dan Geofisika, 2021. [Online]. Tersedia: https://www.bmkg.go.id/iklim/informasi-index-elnino.bmkg. [Diakses: 05- Mar- 2021).

[4] P. Mahmoudi, A. Rigi and M. Miri Kamak, "A comparative study of precipitation-based drought indices with the aim of selecting the best index for drought monitoring in Iran", Theoretical and Applied Climatology, vol. 137, no. 3-4, pp. 3123-3138, 2019. Available: 10.1007/s00704-019-02778-z.

[5] A. Zarei, E. Asadi and A Ebrahimi, "Comparison of Meteorological Indices for SpatioTemporal Analysis of Drought in Chahrmahal-Bakhtiyari Province in Iran", Crotatian Meteorological Journal, no. 13-26, 2017.

[6] S. Dogan, A. Berktay and V. Singh, "Comparison of multi-monthly rainfall-based drought severity indices, with application to semi-arid Konya closed basin, Turkey", Journal of Hydrology, vol. 470-471, pp. 255-268, 2012. Available: 10.1016/j.jhydrol.2012.09.003.

[7] S. Morid, V. Smakhtin and M. Moghaddasi, "Comparison of seven meteorological indices for drought monitoring in Iran", International Journal of Climatology, vol. 26, no. 7, pp. 971-985, 2006. Available: 10.1002/joc.1264.

[8] WMO, Handbook of Drought Indicators and Indices. WMO, 2016

[9] D. Harisuseno, "Meteorological Drought and its Relationship with Southern Oscillation Index (SOI)", Civil Engineering Journal, vol. 6, no. 10, pp. 1864-1875, 2020. Available: 10.28991/cej-2020-03091588.

[10] U. Haryanto, "Keterkaitan Fase SOI Terhadap Curah Hujan Di DAS Citarum", 1998. [Online]. Available: http://repository. ipb.ac.id/ bitstream/handle/ 123456789/4016/ 1998 [Accessed: 05Mar- 2021].

[11] A. Troup, "The 'southern oscillation'", Quarterly Journal of the Royal Meteorological Society, vol. 91, no. 390, pp. 490-506, 1965. Available: 10.1002/qj.49709139009. 